\section{The accounting for ourselves}

\section{Martin J.S. Rudwick}

Theories of Human Evolution: A Century of Debate 1844-1944. By Peter J. Bowler. Basil Blackwell/Johns Hopkins University Press: 1987. Pp.318. £25, \$32.50.

Charles Darwin, in one of the most striking understatements in the history of science, noted at the end of the Origin of Species that through the further development of his theory "light will be thrown on the origin of man and his history". The problem of "man's place in nature", to use T.H. Huxley's phrase, was central to the intensive debates that followed the publication of the Origin, yet the fossil evidence for human evolution remained sparse and highly ambiguous well into the twentieth century. Although the history of palaeoanthropology has been recounted by some of its practitioners, it is only now that post-darwinian research into the origin of the human species has been analysed in detail by an historian of science. Peter Bowler is already well known for his books Fossils and Progress (Science History Publications, 1976) and The Eclipse of Darwinism (Johns Hopkins University Press, 1983); he has now put both historians and palaeoanthropologists in his debt by producing this fine summary of a hundred years of debate about human evolution.

The precise century specified in his subtitle need not be taken too seriously. Bowler really picks up the story at the point when a vast antiquity for the human species first came to be widely accepted, coincidentally in the years immediately before and after the publication of the Origin (1859); and his epilogue carries the story forward well beyond his nominal ending point, to include for example Johanson's 'Lucy' (Australopithecus afarensis) of 1974. That span of history includes the discovery of the Neanderthal fossils, Dubois' Pithecanthropus or 'Java Man', the notorious 'Piltdown Man' and the African australopithecines, to mention only a few. But this is no naively empiricist account of successive fossil finds. Partly as a result of the continuing scarcity of human and near-human fossils, the empirical evidence for human evolution was always open to a wide variety of interpretations; and those interpretations owed almost as much to broad assumptions about human nature as they did to the details of human anatomy. Yet conversely the interpretations were never entirely unconstrained by such evidence as was available; and since the evidence was by its nature cumulative - apart from the aberrant episode of the Piltdown fraud - it can be seen to have exercised increasing constraints on the range of interpretations that could carry scientific conviction.

This feature of the debate would have emerged more clearly from Bowler's account, had he structured his book on more strictly narrative or chronological lines. As it is, his largely topical chapters tend to take the reader to and fro across the decades in a way that makes it difficult to sense the shifting course of opinions about the character of human evolution. He does however show in a striking way how non-darwinian assumptions of an essentially linear and intrinsically progressive trend in human evolution continued to pervade the theorizing of paleoanthropologists, even as late as the 1930s. But it is all the more surprising that he has chosen not to adopt a narrative mode for

\section{Bones of history}

\section{Adrian Desmond}

A Short History of Vertebrate Palaeontology. By Eric Buffetaut. Croom Helm/ Methuen: 1987. Pp.223. £30, \$57.50.

HISTORY might not be bunk, but historians of science have had a hard time proving the point. Since Martin Rudwick published his subtle Meaning of Fossils in 1972, the antique bone-and-biography approaches have been superseded by a number of new contextual studies in geology and palaeontology. These offer a variety of cultural frameworks for appreciating the older interpretations of fossils - interpretations that are often at odds with our own in the late twentieth century.

Eric Buffetaut's book, by contrast, is a tunnel history of the more traditional type. It is written for working scientists, drawing largely upon palaeontological papers and older histories. For all that it is a sprightly and interesting work, especially in its latter part.

Most of the book deals with the formative decades of the nineteenth century, which began with Cuvier's discovery of the succession of fossil faunas. Already in that post-Revolutionary period, when 'revolutions' of the Earth were in vogue, good ichthyosaurs were fetching $£ 150$ and famous fossils such as the Stonesfield 'opossums' could cause academic brawls. Buffetaut discusses the chance discovery of many vertebrate fossils, often as a byproduct of mining activities. It was perhaps the very serendipitous nature of the science that made it attractive to eccentric scholars, not a few of whom ended their careers with suicide (Hugh Miller, Vladimir Kovalevskii, Baron Nopcsa).

Buffetaut rightly hints that less impetus his history, because he is evidently fascinated by Landau's and Cartmill's controversial suggestion that palaeoanthropological accounts of human origins themselves have an irreducibly narrative, and even mythic, structure.

In any case, Bowler himself emphasizes that his account is a preliminary one, and others who want to follow up his leads will be grateful to him for his thorough survey of a vast mass of relevant literature. Like his earlier books, this one is indeed mainly a survey of scientific literature rather than a history of the practice of science. Nonetheless, within the chosen limits of his work, Bowler has compiled a fine account of an evolutionary debate that touches us, perhaps, more nearly than any other.

Martin J.S. Rudwick is Director of the Program in History of Science at Princeton University, Princeton, New Jersey 08544, USA.

was given to fossil studies by darwinism than by the contemporary imperial expansion. The colonists eventually cut down their supplies to Europe's capitals, diverting them to their own regional museums. And with the emergence of large-scale fossil expeditions at the end of the last century, these national museums grew to become themselves cultural showcases proclaiming colonial independence. Buffetaut ends his story at the First World War, when new phylogenetic goals and ecological reconstructions were paving the way for what seem so commonplace today: the museum dioramas.

A history of vertebrate palaeontology in English has long been a desideratum. And even though Buffetaut makes little concession to modern historiography and passes over many specialist historical studies, his Short History provides a baseline for further work. True, professional historians will be miffed at Buffetaut's Whiggish reconstructions - his backdating of discoveries to accord with our modern understanding. (We have Robert Plot, unbeknown to himself, describing dinosaur bones in 1676.) They would also want to see the earlier so-called 'fanciful' theories (for example, explanations of fossils based on the scholastic notion of $v i s$ plastica) treated more sympathetically, perhaps using one of the sociological or philosophical approaches to science now on offer.

Nonetheless, Buffetaut has provided a neat synopsis of fossil discoveries worldwide. His book will prove useful to historians and will appeal to palaeontologists reared on Edwin Colbert's classic Men and Dinosaurs.

Adrian Desmond is an Honorary Research Fellow in the Department of Zoology, University College London, Gower Street, London WC1E 6BT, UK, and author of Archetypes and Ancestors: Palaeontology in Victorian London 1850-1875 (University of Chicago Press, 1984). 